\title{
Relationships between mucosal hydrolysis and transport of two phenylalanine dipeptides
}

\author{
D. B. A. SILK ${ }^{1}$, J. ALEX NICHOLSON, AND Y. S. KIM \\ From the Gastrointestinal Research Laboratory, Veterans Administration Hospital, San Francisco, and \\ the Department of Medicine, University of California, School of Medicine, San Francisco, California, USA
}

SUMMARY In order to investigate the source of free amino acids found in the gut lumen during absorption of dipeptides, as well as evaluating the role of brush border peptidases in the mucosal hydrolysis of dipeptides during absorption, rates of dipeptide disappearance and appearance of hydrolytic products were measured during perfusion of rat jejunum and ileum in vivo with buffered and unbuffered $10 \mathrm{mM}$ solutions of glycyl-L-phenylalanine (Gly-Phe) and L-phenylalanyl-glycine (Phe-Gly). Mucosal brush border peptidase activity was then measured in the perfused segments in vitro at luminal $\mathrm{pH}$ and at two substrate concentrations. In addition cytosol peptidase activity in the perfused segments was measured at $\mathrm{pH} 7.4$ and at $10 \mathrm{mM}$ substrate concentrations. In the jejunum, there was a relationship between rates of free phenylalanine appearance in vivo (Phe-Gly $>$ Gly-Phe) and rates of brush border (Phe-Gly $>$ Gly-Phe) rather than cytosol (Gly-Phe $>$ Phe-Gly) peptidase activities. No constant relationship between free phenylalanine appearance and hydrolysis of the dipeptides by either brush border or cytosol peptidases was observed in the ileal studies. These findings suggest that, in the jejunum, hydrolytic products originate from the surface of the cell whereas, in the ileum, hydrolytic products originate from both the intracellular compartment as well as from the surface of the mucosal cell. In the jejunum, in vitro rates of brush border hydrolysis of Gly-Phe were always less than in vivo disappearance rates, whereas rates of Phe-Gly brush border hydrolysis always exceeded luminal disappearance rates. These data imply that Gly-Phe is predominantly transported intact and hydrolysed by cytosol peptidases. In contrast, brush border peptidases play an important role in the mucosal hydrolysis of Phe-Gly.

Although a few dipeptides with a low affinity for intestinal mucosal peptidases have been detected in peripheral and portal plasma during absorption experiments (Peters and MacMahon, 1970; Adibi, 1971; Boullin et al., 1973), most dipeptides removed from the lumen of the small intestine during the processes of protein digestion and absorption (Silk, 1974; Matthews, 1975; Matthews and Adibi, 1976) are hydrolysed by intestinal mucosal peptidases.

The subcellular mucosal site or sites of dipeptide hydrolysis are unclear at present. On the one hand, results of many experiments have been interpreted as indicating that dipeptides are hydrolysed by intracellular enzymes (Adibi, 1971; Matthews, 1971; Silk, 1974; Matthews, 1975). These conclusions are

\footnotetext{
${ }^{1}$ Address for correspondence: Dr D. B. A. Silk, Liver Unit, King's College Hospital, London S.E.5.
}

Received for publication 28 June 1976 supported by (1) subcellular fractionation studies, which show that mucosal dipeptidase activity is predominantly located to the cytoplasmic compartment of the cell (Robinson, 1963; Peters, 1970; Donlon and Fottrell, 1972), and (2) the recent characterisation of a carrier mediated transport system for di- and tripeptides (Addison et al., 1972; Matthews et al., 1974; Addison et al., 1975a; Addison et al., 1975b; Sigrist-Nelson, 1975).

On the other hand a common finding in almost all in vivo and in vitro dipeptide absorption experiments has been the detection of dipeptide hydrolytic products (amino acids) in the medium bathing the intestinal mucosa (Silk, 1974; Matthews, 1975; Matthews and Adibi, 1976). The source of free amino acids produced during dipeptide absorption has not been determined, but their presence has been taken to indicate that some hydrolysis of dipeptides occurs at the surface of the mucosal cell (Adibi, 1971; 
Cheng et al., 1971; Silk et al., 1973). Supporting a superficial site of hydrolysis, recent studies indicate that the brush border fraction as well as the cytosol fraction of intestinal mucosa contains a number of enzymes capable of hydrolysing a wide variety of dipeptides (Rhodes et al., 1967; Kim et al., 1972; Fujita et al., 1972; Heizer et al., 1972; Wojnarowska and Gray, 1975; Kim and Brophy, 1976; Kim et al., 1976). The activity of these enzymes is high, even in relationship to sucrase (Auricchio et al., 1972) and it has therefore been suggested that they play a role in the terminal stages of protein digestion at the peptide level (Rhodes et al., 1967; Kim et al., 1972; Fujita et al., 1972; Heizer et al., 1972; Wojnarowska and Gray, 1975).

In this paper we report experiments that were undertaken to further investigate the mucosal hydrolysis of dipeptides with the aim of (1) determining the source or sources of free amino acids detected during jejunal and ileal perfusion of dipeptides in vivo, and (2) evaluating the role of brush border enzymes in the mucosal hydrolysis of dipeptides during absorption in vivo. Using two substrates glycyl-L-phenylalanine (Gly-Phe) and Lphenylalanyl-glycine (Phe-Gly) dipeptide disappearance rates and free amino acid appearance rates were measured during in vivo perfusion of rat intestine. Rates of hydrolysis of the peptides by mucosal brush border peptidases, obtained from the mucosa of the perfused segments, were then measured in vitro at the $\mathrm{pH}$ of intestinal contents and mucosal cytosol peptidase activity measured at $\mathrm{pH}$ 7.4. In this way, relationships between enzyme activities, disappearance of luminal substrate, and luminal appearance of the products of dipeptide hydrolysis could be examined. Initially, perfusion experiments were performed using unbuffered solutions. The $\mathrm{pH}$ of jejunal and ileal contents was different; as activities of intestinal mucosal peptidases are $\mathrm{pH}$ dependent (Kim et al., 1974) the $\mathrm{pH}$ of jejunal and ileal contents was reversed by perfusing buffered solutions so that the above relationships could be examined in more detail.

\section{Methods}

PERFUSION PROCEDURE AND TISSUE PREPARATION

Unfasted female Wistar rats (220-240 g) were used for all experiments, since it is known that fasting has a deleterious effect on mucosal brush border peptide hydrolase activity (Kim et al., 1973). 20-25 cm segments of rat jejunum or ileum were prepared and perfused as previously described (Lane et al., 1975). Test solutions were perfused at $0.3 \mathrm{ml} / \mathrm{min}$ and, after a 30 minute equilibration period for each solution, a single 10 minute collection of intestinal contents was made and the $\mathrm{pH}$ measured immediately. Three additional 10 minute collections were then made into tubes positioned in a mixture of dry ice and ethanol. These samples were then boiled to inactivate possible luminal peptidases.

At the end of the perfusion experiments, the jejunal and ileal loops were removed and transferred to a cold room maintained at $4^{\circ} \mathrm{C}$. Mucosae were scraped, the scrapings weighed and immediately homogenised in $14 \%$ glycerol $(20 \mathrm{ml} / \mathrm{g})$.

CHOICE OF SUBSTRATES AND

COMPOSITION OF PERFUSION SOLUTIONS

The dipeptides Gly-Phe and Phe-Gly were chosen as substrates because mucosal brush border peptidase activity in mucosal homogenates can be readily distinguished from mucosal cytosol activity by the different sensitivities of the enzymes in these two fractions to the inhibitor p-hydroxy mercuribenzoate (PHMB, Heizer et al., 1972; Nicholson and Kim, 1975). For the first series of experiments, $10 \mathrm{mM}$ concentrations of Gly-Phe and Phe-Gly were dissolved in $140 \mathrm{mM}$ sodium chloride. $4 \mathrm{~g} / 1$ polyethylene glycol (PEG) labelled with $2 \mu \mathrm{Ci}{ }^{14} \mathrm{C}$ PEG/l was added and the solutions adjusted to $\mathrm{pH} \mathrm{7.0} \mathrm{with}$ $0 \cdot 1 \mathrm{M} \mathrm{NaOH}$.

In the second series of experiments jejunal solutions were prepared by adding dipeptide (final concentration $10 \mathrm{mM}$ ) to Krebs Henseleit Ringer bicarbonate (KHRB) buffer $\mathrm{pH} 7 \cdot 4$. Ileal solutions were prepared by adding dipeptide to $75 \mathrm{mM}$ acetic acid: sodium acetate buffer pH 5.4 and the resultant mixture made isotonic by adding sodium chloride.

CHEMICAL ANALYSIS OF INTESTINAL CONTENTS

Suitably diluted aliquots of intestinal contents were assayed for free L-phenylalanine (Phe) using the L-amino acid oxidase reagent described by Nicholson and Kim (1975). Previous studies in this laboratory have shown that neither glycine, Gly-Phe or PheGly react with L-amino acid oxidase (Nicholson and Kim, 1975). Concentrations of unhydrolysed dipeptide were estimated from the difference between concentrations of Phe in intestinal contents after and before acid hydrolysis. $0.5 \mathrm{ml}$ intestinal content was mixed with $0.5 \mathrm{ml} 6 \mathrm{~N} \mathrm{HCl}$, and incubated in sealed glass tubes at $110^{\circ} \mathrm{C}$ for $20 \mathrm{hr}$. Hydrolysates were then neutralised and assayed for free Phe. When intestinal contents collected during perfusion of isotonic saline were assayed as described above, absorbance readings corresponded to less than $1 \cdot 2$ nmol Phe.C ${ }^{14}$ PEG was estimated as previously described (Silk et al., 1974). 
IN VITRO ASSAY OF MUCOSAL PEPTIDASE ACTIVITIES

It is necessary during the process of absorption for molecules to pass through the unstirred water layer (Dietschy et al., 1971) as well as the lipid membrane of the microvillus surface. The unstirred water layer has been shown to distort the kinetic parameters of carrier mediated transport processes for hydrophilic solutes in vitro (Wilson and Dietschy, 1974). In the present study, concentrations of dipeptide in the bulk water phase of the small intestinal lumen may be greater than at the surface of the mucosal cells. The magnitude of this difference is unknown, but, in order to obviate possible effects of the unstirred water layer on juxta mucosal concentrations of dipeptide, all assays of brush border peptidase activity were carried out at infusion substrate concentration $(10 \mathrm{mM})$ and also at $2 \mathrm{mM}$. Initial rates of dipeptide hydrolysis by cytosol and brush border peptidases in mucosal homogenates were measured over a 20 minute period in the absence and presence of $0.5 \mathrm{mM}$ PHMB using a two step L-amino acid oxidase method (Nicholson and Kim, 1975). Substrates were dissolved in the following buffers: (1) $50 \mathrm{mM}$ Tris-maleate buffer for estimation of brush border peptide hydrolase activity after the salinedipeptide perfusions. The $\mathrm{pH}$ was adjusted to the $\mathrm{pH}$ of intestinal contents. (2) KHRB buffer $\mathrm{pH} 7.4$ for estimation of brush border peptide hydrolase activity after jejunal perfusion of dipeptides dissolved in this buffer. (3) $50 \mathrm{mM}$ Tris-maleate buffer pH 5.7 for estimation of ileal brush border enzyme activity after ileal perfusion of dipeptide dissolved in $75 \mathrm{mM}$ acetic acid: sodium acetate buffer. (4) $50 \mathrm{mM}$ Tris-maleate buffer $\mathrm{pH} 7.4$ for estimation of jejunal and ileal cytosol peptide hydrolase activity.

\section{CAlCulation OF DATA}

Disappearance rates of unhydrolysed dipeptide, and appearance rates of free Phe during the in vivo dipeptide perfusions were calculated from standard formulae (Adibi, 1971) and results expressed as $\mu \mathrm{mol} / \mathrm{h} / \mathrm{g}$ mucosal scrapings. For the in vitro enzyme assays, mucosal brush border peptidase activity is the activity observed in the presence of PHMB, and cytosol peptidase activity is the activity in the ab- sence of PHMB minus the activity observed in its presence (Silk and Kim, 1975). Results are expressed as $\mu \mathrm{mol}$ dipeptide hydrolysed $/ \mathrm{h} / \mathrm{g}$ mucosal scrapings. The statistical significance of differences in results was evaluated by the paired $t$ test and by Student's $t$ test where appropriate.

\section{Results}

PH OF INTESTINAL CONTENTS

The pH of intestinal contents is shown in Table 1. During the dipeptide-saline perfusions jejunal contents had a lower $\mathrm{pH}$ than ileal contents. Jejunal perfusion of dipeptides dissolved in KHRB buffer resulted in luminal $\mathrm{pH}$ values very similar to those found during ileal perfusion of dipeptide-saline mixtures. Similarly, ileal perfusion of dipeptides dissolved in acetic acid: sodium acetate buffer resulted in luminal $\mathrm{pH}$ values similar to those found during jejunal perfusion of dipeptide-saline mixtures.

FREE PHENYLALANINE APPEARANCE AND MUCOSAL DIPEPTIDE HYDROLYSIS

\section{Dipeptide-saline perfusions (Table 2)}

When the unbuffered dipeptide-saline solutions were perfused in the jejunum, Phe appeared faster during Phe-Gly perfusion than Gly-Phe perfusion $(P<0.05)$. Table 2 shows that at $10 \mathrm{mM}$ substrate concentration brush border peptidase activity was greater for PheGly than Gly-Phe $(P<0.005)$. This was also the case when $2 \mathrm{mM}$ substrate concentrations were used in the assays $(P<0.005)$. In contrast, cytosol peptidase activity was 10 times greater for Gly-Phe than PheGly ( $P<0.001)$. When the same solutions were perfused in the ileum, Phe appeared faster during GlyPhe perfusion than Phe-Gly perfusion $(P<0.02)$. As in the jejunum, brush border peptidase activity was greater for Phe-Gly than Gly-Phe at both substrate concentiations ( $P<0.02$ or less) and cytosol peptidase activity was greater for Gly-Phe than PheGly (P < 0.001).

Buffered dipeptide perfusions (Table 3)

Phe appearance during jejunal perfusion of Gly-Phe and Phe-Gly increased when the jejunal luminal pH

Table 1 pH of intestinal contents*

\begin{tabular}{|c|c|c|c|c|}
\hline \multirow{2}{*}{$\begin{array}{l}\text { Composition of perfusion } \\
\text { solutions }\end{array}$} & \multicolumn{2}{|l|}{ Jejunum } & \multicolumn{2}{|l|}{ Ileum } \\
\hline & Gly-Phe & Phe-Gly & Gly-Phe & Phe-Gly \\
\hline $\begin{array}{l}\text { Dipeptide-saline (pH 7.0) } \\
\text { Dipeptide-buffer } \dagger\end{array}$ & $\begin{array}{l}5 \cdot 3-6 \cdot 2 \\
7 \cdot 0-7 \cdot 5\end{array}$ & $\begin{array}{l}5 \cdot 6-6 \cdot 1 \\
7 \cdot 0-7 \cdot 4\end{array}$ & $\begin{array}{l}6 \cdot 9-7 \cdot 5 \\
5 \cdot 4-6 \cdot 0\end{array}$ & $\begin{array}{l}6 \cdot 7-7 \cdot 9 \\
5 \cdot 4-5 \cdot 9\end{array}$ \\
\hline
\end{tabular}

*Values are range, $n=6$.

†Dipeptides (final concentration $10 \mathrm{mM}$ ) dissolved in pH $7 \cdot 4$ Krebs Henseleit Ringer bicarbonate buffer for the jejunal perfusions and pH $5 \cdot 4$ acetic aoid: sodium acetate buffer for the ileal perfusions. 
Table 2 Free phenylalanine appearance during in vivo perfusion of unbuffered $10 \mathrm{mM}$ dipeptide-saline solutions, mucosal brush border peptidase activity in perfused segments measured in vitro at luminal pH and at $10 \mathrm{mM}$ substrate concentration and mucosal cytosol peptidase activity in perfused segments measured in vitro at pH 7.4 and at $10 \mathrm{mM}$ substrate concentration

\begin{tabular}{|c|c|c|c|c|}
\hline \multirow[b]{3}{*}{$\begin{array}{l}\text { Free Phe appearance } \\
(\mu \mathrm{mol} / \mathrm{h} / \mathrm{g} \text { mucosa })\end{array}$} & \multicolumn{2}{|c|}{ Jejunum $(p H 5 \cdot 3-6 \cdot 2)$} & \multicolumn{2}{|c|}{ Ileum (pH 6.7-7.9) } \\
\hline & Gly-Phe & Phe-Gly & Gly-Phe & Phe-Gly \\
\hline & $0.01 \pm 0.01$ & $0.76 \pm 0.38$ & $7.53 \pm 1.06$ & $4.41 \pm 0.62$ \\
\hline $\begin{array}{l}\text { Brush border peptidase activity } \\
(\mu \mathrm{mol} / \mathrm{h} / \mathrm{g} \text { mucosa })\end{array}$ & $38.4 \pm 10.0$ & $295 \cdot 4 \pm 37 \cdot 1$ & $165 \cdot 5 \pm 39 \cdot 8$ & $312 \cdot 2 \pm 47 \cdot 3$ \\
\hline $\begin{array}{l}\text { Cytosol peptidase activity } \\
\mathrm{mmol} / \mathrm{h} / \mathrm{g}\end{array}$ & $7.5 \pm 0.6$ & $0.7 \pm 0.1$ & $9.3 \pm 0.7$ & $0.4 \pm 0.0$ \\
\hline
\end{tabular}

Values are the mean $\pm S E, n=6$.

Table 3 Free phenylalanine appearance during in vivo perfusion of buffered $10 \mathrm{mM}$ dipeptide solutions, mucosal brush border peptidase activity in perfused segments measured in vitro at luminal pH and at $10 \mathrm{mM}$ substrate concentration, and mucosal cytosol peptidase activity in perfused segments measured in vitro at pH 7.4 and at $10 \mathrm{mM}$ substrate concentration

\begin{tabular}{|c|c|c|c|c|}
\hline & \multicolumn{2}{|c|}{ Jejunum $(p H 7 \cdot 0-7 \cdot 5)$} & \multicolumn{2}{|c|}{ Ileum (pH 5.4-6.0) } \\
\hline & Gly-Phe & Phe-Gly & Gly-Phe & Phe-Gly \\
\hline $\begin{array}{l}\text { Free Phe appearance } \\
(\mu \mathrm{mol} / \mathrm{h} / \mathrm{g} \text { mucosa })\end{array}$ & $1.82 \pm 0.96$ & $48.2 \pm 1.42$ & $3.53 \pm 0.64$ & $3.36 \pm 0.26$ \\
\hline $\begin{array}{l}\text { Brush border peptidase activity } \\
\left(\mu \mathrm{mol} / \mathrm{h}^{6} \mathrm{~g} \text { mucosa }\right)\end{array}$ & $329 \cdot 8 \pm 31 \cdot 2$ & $1725.0 \pm 91.6$ & $4 \cdot 2 \pm 2 \cdot 8$ & $72 \cdot 8 \pm 12 \cdot 6$ \\
\hline $\begin{array}{l}\text { Cytosol peptidase activity } \\
\mathrm{mmol} / \mathrm{h} / \mathrm{g}\end{array}$ & $7.5 \pm 0.6$ & $0.7 \pm 0.1$ & $9 \cdot 3 \pm 0.7$ & $0.4 \pm 0.0$ \\
\hline
\end{tabular}

Values are the mean $\pm S E, n=6$.

Table 4 Rates of dipeptide disappearance during in vivo perfusion of $10 \mathrm{mM}$ unbuffered dipeptide-saline solutions and mucosal brush border peptidase activity in perfused segments measured in vitro at luminal pH and at $2 \mathrm{mM}$ and $10 \mathrm{mM}$ substrate concentrations

\begin{tabular}{|c|c|c|c|c|}
\hline \multirow[t]{2}{*}{ ( $\mu \mathrm{mol} / \mathrm{h} / \mathrm{g}$ mucosa) } & \multicolumn{2}{|c|}{ Jejunum $(p H 5 \cdot 3-6 \cdot 2)$} & \multicolumn{2}{|c|}{ Ileum $(p H$ 6.7-7.9) } \\
\hline & Gly-Phe & Phe-Gly & Gly-Phe & Phe-Gly \\
\hline $\begin{array}{l}\text { Dipeptide disappearance } \\
\text { Brush border peptidase activity }\end{array}$ & $77 \cdot 7 \pm 8.5$ & $75 \cdot 5 \pm 9 \cdot 7$ & $67 \cdot 5 \pm 8 \cdot 8$ & $74 \cdot 3 \pm 4 \cdot 1$ \\
\hline $\begin{array}{l}(2 \mathrm{mM}) \\
(10 \mathrm{mM})\end{array}$ & $\begin{array}{l}26.4 \pm 11.0 \\
38.4 \pm 10.0\end{array}$ & $\begin{array}{l}101 \cdot 4 \pm 11 \cdot 0 \\
295 \cdot 4 \pm 37 \cdot 1\end{array}$ & $\begin{array}{r}69.5 \pm 13.6 \\
165.5 \pm 39 \cdot 8\end{array}$ & $\begin{array}{l}246 \cdot 6 \pm 26 \cdot 1 \\
312 \cdot 2 \pm 47 \cdot 3\end{array}$ \\
\hline
\end{tabular}

Values are the mean $\pm S E, n=6$.

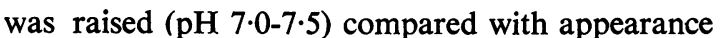
rates seen during the jejunal dipeptide-saline perfusions $(P<0.05$ for both dipeptides). Similarly, jejunal mucosal brush border peptidase activity for both dipeptides at the two substrate concentrations was also greater when measured at the $\mathrm{pH}$ of buffered than unbuffered intestinal contents $(P<$ 0.05 or less). As during the jejunal dipeptide saline perfusions (Table 2), Phe appearance during the buffered perfusions was greater for Phe-Gly than Gly-Phe $(P<0.02)$ and brush border peptidase activity was also greater for Phe-Gly than Gly-Phe (P $<0.001)$.

Ileal mucosal brush border peptidase activity for both dipeptides at the two substrate concentrations was reduced when measured at the lower $\mathrm{pH}$ of the buffered ( $\mathrm{pH} \mathrm{5 \cdot 4-6.0)}$ than unbuffered ( $\mathrm{pH}$ 6.7-7.9) ileal contents ( $\mathrm{P}<0.05$ or less). As during the ileal dipeptide-saline perfusions (Table 2) brush border peptidase activity was greater for Phe-Gly than GlyPhe (P $<0.05$ or less). Phe appearance rates during the buffered ileal perfusions was the same for GlyPhe and Phe-Gly.

DIPEPTIDE DISAPPEARANCE RATES AND BRUSH BORDER PEPTIDASE ACTIVITIES

Dipeptide-saline perfusions (Table 4)

Rates of brush border hydrolysis of Phe-Gly (measured at the same $\mathrm{pH}$ of intestinal contents using $2 \mathrm{mM}$ and $10 \mathrm{mM}$ substrate concentrations) were the same $(2 \mathrm{mM})$ or greater $(10 \mathrm{mM})$ than the rates of disappearance of unhydrolysed Phe-Gly from the gut lumen during jejunal and ileal perfusion of the unbuffered $(10 \mathrm{mM})$ dipeptide-saline solutions. The same was the case during the ileal experiments with 
Table 5 Rates of dipeptide disappearance during in vivo perfusion of $10 \mathrm{mM}$ buffered dipeptide solutions and mucosal brush border peptidase activity in perfused segments measured in vitro at luminal pH and at $2 \mathrm{mM}$ and $10 \mathrm{mM}$ substrate concentrations

\begin{tabular}{|c|c|c|c|c|}
\hline \multirow[t]{2}{*}{ ( $\mu \mathrm{mol} / \mathrm{h} / \mathrm{g}$ mucosa) } & \multicolumn{2}{|c|}{ Jejunum $(p H 7 \cdot 0-7 \cdot 5)$} & \multicolumn{2}{|c|}{ Ileum (pH 5.4-6.0) } \\
\hline & Gly-Phe & Phe-Gly & Gly-Phe & Phe-Gly \\
\hline $\begin{array}{l}\text { Dipeptide disappearance } \\
\text { Brush border peptidase activity }\end{array}$ & $81 \cdot 3 \pm 7 \cdot 0$ & $80.8 \pm 4.4$ & $87 \cdot 2 \pm 4 \cdot 8$ & $80.1 \pm 7.2$ \\
\hline $\begin{array}{l}(2 \mathrm{mM}) \\
(10 \mathrm{mM})\end{array}$ & $\begin{array}{r}39.1 \pm 10.0 \\
329.8 \pm 31 \cdot 2\end{array}$ & $\begin{array}{l}1131 \cdot 0 \pm 48 \cdot 1 \\
1725 \cdot 0 \pm 91 \cdot 6\end{array}$ & $\begin{array}{l}1.9 \pm 1.9 \\
4.2 \pm 2.8\end{array}$ & $\begin{array}{l}24 \cdot 6 \pm 7 \cdot 6 \\
72 \cdot 8 \pm 12 \cdot 6\end{array}$ \\
\hline
\end{tabular}

Values are the mean $\pm \mathrm{SE}, \mathrm{n}=6$

Gly-Phe, but hydrolysis of Gly-Phe by brush border peptidases in jejunal mucosa was less than jejunal disappearance rates of the dipeptide.

BUFFERED DIPEPTIDE PERFUSIONS (Table 5) Altering the luminal $\mathrm{pH}$ did not significantly affect jejunal or ileal disappearance rates of either dipeptide. Thus, values of jejunal Phe-Gly brush border peptidase activity, measured at two substrate concentrations and at the $\mathrm{pH}$ of buffered jejunal contents, were several times greater than luminal disappearance rates. In the case of Gly-Phe, jejunal brush border peptidase activity measured at $10 \mathrm{mM}$ substrate concentration was also greater than the rates of luminal disappearance, but enzyme activity measured at $2 \mathrm{mM}$ was less than the rate of luminal disappearance. In the ileal experiments, when luminal pH was lowered, brush border activities for both the dipeptides, under all assay conditions, were less than luminal disappearance rates.

\section{Discussion}

A common finding in almost all in vivo and in vitro dipeptide absorption experiments has been the detection of dipeptide hydrolytic products (amino acids) in media bathing intestinal mucosal preparations (Silk, 1974; Matthews, 1975; Matthews and Adibi, 1976). These amino acids could arise asa result of (1) hydrolysis of dipeptides by peptidases in the medium, (2) hydrolysis of dipeptides by mucosal brush border peptidases, with subsequent diffusion of liberated amino acids into the medium, or (3) hydrolysis of dipeptides by mucosal cytoplasmic peptidases with subsequent movement of liberated amino acids out of the intracellular compartment back into the medium. The first alternative may be of major importance in in vitro experiments since mucosal peptidases are rapidly secreted into the medium (Josefsson and Sjöstrom, 1966; Silk and $\mathrm{Kim}, 1976)$. However, in in vivo perfusion experiments luminal peptidase activity is low (Adibi, 1971; Silk et al., 1973; Lane et al., 1975), and does not significantly contribute to the production of free amino acids detected during dipeptide perfusion. The first aim of the present study was therefore to determine if appearance of free amino acids during in vivo dipeptide transport is related to brush border or cytoplasmic peptidase activity.

When unbuffered solutions of Gly-Phe and PheGly were perfused in the jejunum, free Phe appearance was greater during perfusion of Phe-Gly than Gly-Phe. Brush border peptidase activity measured at luminal pH (5.3-6.2) was greater for Phe-Gly than Gly-Phe. In marked contrast cytosol peptidase activity (measured at $\mathrm{pH} \mathrm{7.4)}$ was 10 times greater for Gly-Phe than for Phe-Gly. These data suggest that appearance rates of free Phe during jejunal perfusion of the two dipeptides is a function of the relative rates of hydrolysis of the two dipeptides by brush border rather than cytosol peptidases. This conclusion is supported by the results of buffered perfusions. When luminal $\mathrm{pH}$ was raised from $\mathrm{pH}$ range 5.3-6.2 to 7.0-7.5 in vivo rates of free Phe appearance during perfusion of both dipeptides increased as did in vitro rates of brush border hydrolysis. Furthermore, the differential between rates of appearance of free Phe and rates of hydrolysis of the dipeptides was maintained (Table 3).

In the ileum, Phe appearance rates were greater for both dipeptides than in the jejunum, when the dipeptide-saline mixtures were perfused (Table 2). At first sight this seemed to be because brush border peptidase activity against the two dipeptides was greater in ileal than jejunal mucosa when assays were carried out at luminal pH. However, in contrast with the jejunal studies, there was no relationship between differential rates of ileal Phe appearance and brush border peptidase activity for the two dipeptides. This was also the case when the ileal perfusions were repeated using buffered dipeptide solutions. Indeed, during the ileal dipeptide-saline perfusions there was a relationship between the differential rates of Phe appearance and cytosol peptidase activity against the two dipeptides. The present study has not therefore been helpful in determining why free amino acid appearance is greater during ileal rather than jejunal perfusions (Adibi, 1971; Silk et al., 1974b; Lane et al., 
1975). The results do suggest however that the origin of these free amino acids is quite different in the ileum compared with the jejunum. One possibility is that in the ileum free amino acids move from the intracellular compartment to the mucosal medium after dipeptide hydrolysis by cytoplasmic peptidases (Boyd et al., 1975). Further studies are needed, however, before firm conclusions can be drawn about the source of luminal free amino acids during ileal dipeptide perfusion.

The jejunum is currently thought to be the major site of absorption of protein digestion products (Borgström et al., 1957; Nixon and Mawer, 1970). Here, although rates of disappearance of the two dipeptides were the same, rates of appearance of free Phe and brush border peptidase activity were greater for Phe-Gly than Gly-Phe. This suggests that greater proportions of luminal Phe-Gly than GlyPhe are hydrolysed at the surface of the cell during absorption. Determination of the precise amounts of either dipeptide hydrolysed at the surface of the cell is difficult. Free amino acids in the lumen represent only those proportions of released amino acids that have not been absorbed, and have diffused across the unstirred layer into the bulk phase. The simultaneous estimation of in vivo transport rates and in vitro brush border hydrolysis rates allows some conclusions to be drawn about the overall contribution of brush border peptidases in the mucosal hydrolysis of luminal dipeptides. In the case of Gly-Phe, rates of hydrolysis were less than half rates of luminal disappearance. Thus, it is probable that substantial quantities of this dipeptide are absorbed intact.

In the case of Phe-Gly, rates of brush border hydrolysis were greater than luminal disappearance rates. The conditions of the in vitro enzyme assays are not necessarily the same as the conditions of the in vivo perfusion experiments. Comparisons of in vivo disappearance rates and in vitro hydrolysis rates are thus subject to a number of limitations. Firstly, concentrations of substrate at the aqueous-lipid interface may be lower than in the bulk perfusion solution (Wilson and Dietschy, 1974). To circumvent this problem brush border peptidase activities were measured at one-fifth infusion concentration as well as at infusion concentration. Even at the lower substrate concentration jejunal Phe-Gly brush border peptidase activity was still greater than jejunal PheGly disappearance rates during perfusion of the dipeptide saline mixture (Table 4). Secondly, although enzyme assays were performed at luminal $\mathrm{pH}$, the $\mathrm{pH}$ in the bulk phase of the gut lumen and at the surface of the cell may not necessarily be the same. Indeed surface $\mathrm{pH}$ of rat everted sacs in vitro, measured with a pH microelectrode was less than the
$\mathrm{pH}$ of the incubation medium (Lucas et al., 1975). However, in the present experiments, test solutions were perfused for 30 minutes before samples were collected for analysis. Surface $\mathrm{pH}$ values in vitro moved towards luminal $\mathrm{pH}$ values with time (Lucas et al., 1975), but to date there is no evidence that such changes in surface $\mathrm{pH}$ occur in vivo. Finally, while the catalytic sites of brush border peptidases are located on the luminal surface of the microvillus membrane (Louvard et al., 1975), luminal substrate is not necessarily exposed to the entire surface area of the villi in vivo. It is of interest, though, that brush border peptidase activity is concentrated at the tips of the villi, the area maximally exposed to luminal substrate (Y. S. Kim, unpublished data).

Bearing these limitations in mind, the fact remains that rates of jejunal hydrolysis of Phe-Gly by brush border peptidases were 1.3 to four times greater than rates of dipeptide disappearance. This suggests that, unlike Gly-Phe, the major site of mucosal hydrolysis of Phe-Gly is not necessarily within the cytoplasmic compartment of the cell. Recently, two rat intestinal brush border peptidases have purified to homogeneity (Kim and Brophy, 1976). Studies of the substrate specificity of the two enzymes indicated that, in addition to Phe-Gly, other dipeptides composed of neutral amino acid residues were also rapidly hydrolysed (Kim et al., 1976). The possibility exists, therefore, that while certain peptides such as GlyPhe are predominantly absorbed intact and hydrolysed by intracellular peptidases, brush border peptidases may play an important role in the mucosal hydrolysis of other dipeptides such as Phe-Gly.

This work was supported by Public Health Service Grant AM-19738 from the National Institute of Health. D.B.A.S. was in receipt of a Medical Research Council Travelling Fellowship.

\section{References}

Addison, J. M., Burston, D., Dalrymple, J. A., Matthews, D. M., Payne, J. W., Sleisenger, M. H., and Wilkinson, S. (1975a). A common mechanism for transport of di- and tri-peptides by hamster jejunum in vitro. Clinical Science and Molecular Medicine, 49, 313-322.

Addison, J. M., Burston, D., and Matthews, D. M. (1972). Evidence for active transport of the dipeptide glycylsarcosine by hamster jejunum in vitro. Clinical Science, 43, 907911.

Addison, J. M., Burston, D., Payne, J. W., Wilkinson, S., and Matthews, D. M. (1975b). Evidence for active transport of tripeptides by hamster jejunum in vitro. Clinical Science and Molecular Medicine, 49, 305-312.

Adibi, S. A. (1971). Intestinal transport of dipeptides in man: relative importance of hydrolysis and intact absorption. Journal of Clinical Investigation, 50, 2266-2275.

Auricchio, S., Pierro, M., Andria, G., and DeRitis, G. (1972). Enzymic activities of the brush border membrane of rat intestine hydrolysing naphthylamides of amino acids, 
leucinamide and dipeptides. Biochimica et Biophysica Acta, 274, 420-425.

Borgström, B. A., Dahlqvist, A., Lundh, G., and Sjövall, J. (1975). Studies of intestinal digestion and absorption in the human. Journal of Clinical Investigation, 36, 1521-1536.

Boullin, D. J., Crampton, R. F., Heading, C. E., and Pelling, D. (1973). Intestinal absorption of dipeptides containing glycine, phenylalanine, proline, $\beta$-alanine or histidine in the rat. Clinical Science and Molecular Medicine, 45, 849-858.

Boyd, C. A. R., Cheeseman, C. I., and Parsons, D. S. (1975). Amino acid movements across the wall of anuran small intestine perfused through the vascular bed. Journal of Physiology, 250, 409-429.

Cheng, B., Navab, F., Lis, M. T., Miller, T.N., and Matthews, D. M. (1971). Mechanisms of dipeptide uptake by rat small intestine in vitro. Clinical Science, 40, 247-257.

Dietschy, J. M., Sallee, V. L., and Wilson, F. A. (1971). Unstirred water layers and absorption across the intestinal mucosa. Gastroenterology, 61, 932-934.

Donlon, J., and Fottrell, P. F. (1972). Studies on sustrate specificities and subcellular location of multiple forms of peptide hydrolases in guinea pig intestinal mucosa. Comparative Biochemistry and Physiology, 41B, 181-193.

Fujita, M., Parsons, D. S., and Wojnarowska, F. (1972). Oligopeptidases of brush border membranes of rat small intestinal mucosal cells. Journal of Physiology, 227, 377 394.

Heizer, W. D., Kerley, R. L., and Isselbacher, K. J. (1972). Intestinal peptide hydrolases: differences between brush border and cytoplasmic enzymes. Biochimica et Biophysica Acta, 264, 450-461.

Josefsson, L., and Sjöström, H. (1966). Intestinal dipeptidases. 4. Studies on the release and subcellular distribution of intestinal dipeptidases of the mucosal cells of the pig. Acta Physiologica Scandinavica, 67, 27-33.

Kim, Y. S., Birtwhistle, W., and Kim, Y. W. (1972). Peptide hydrolases in the brush border and soluble fractions of small intestinal mucosa of rat and man. Journal of Clinical Investigation, 51, 1419-1430.

Kim, Y. S., and Brophy, E. J. (1976). Rat intestinal brush border membrane peptidases. 1. Solubilization, purification and physico-chemical properties of two different forms of the enzyme. Journal of Biological Chemistry, 251, 3199-3205.

Kim, Y. S., Brophy, E. J., and Nicholson, J. A. (1976). Rat intestinal brush border membrane peptidases. 2. Enzymatic properties, immunochemistry and interactions with lectins of two different forms of the enzyme. Journal of Biological Chemistry, 251, 3206-3211.

Kim, Y. S., Kim, Y. W., and Sleisenger, M. H. (1974). Studies on the properties of peptide hydrolases in the brush-border and soluble fractions of small intestinal mucosa of rat and man. Biochimica et Biophysica Acta, 370 , 283-296.

Kim, Y. S., McCarthy, D. M., Lane, W., and Fong, W. (1973). Alterations in the levels of peptide hydrolases and other enzymes in the brush border and soluble fractions of rat small intestinal mucosa during starvation and refeeding. Biochimica et Biophysica Acta, 321, 262-273.

Lane, A. E., Silk, D. B. A., and Clark, M. L. (1975). Absorption of two proline containing peptides by rat small intestine in vivo. Journal of Physiology, 248, 143-149.

Louvard, D., Maroux, S., Vannier, C., and Desnuelle, P. (1975). Topological studies on the hydrolases bound to the intestinal brush border membrane. 1. Solubilization by papain and Triton X-100. Biochimica et Biophysica Acta,
375 (2), 236-248.

Lucas, M. L., Blair, J. A., Cooper, B., and Matty, A. J. (1975). Further investigations with $\mathrm{pH}$ microelectrodes into the jejunal microclimate in rat and man. Gut, 16, 844.

Matthews, D. M. (1971). Protein absorption. Journal of Clinical Pathology, 24, suppl. 5, 29-40.

Matthews, D. M. (1975). Intestinal absorption of peptides. Physiological Reviews, 55, 537-608.

Matthews, D. M., Addison, J. M., and Burston, D. (1974). Evidence for active transport of the dipeptide carnosine ( $\beta$-alanyl-L-histidine) by hamster jejunum in vitro. Clinical Science and Molecular Medicine, 46, 693-705.

Matthews, D. M., and Adibi, S. A. (1976). Gastroenterology, 71, 151-161.

Nicholson, J. A., and Kim, Y. S. (1975). A one-step L-amino acid oxidase assay for intestinal peptide hydrolase activity. Analytical Biochemistry, 63, 110-117.

Nixon, S. E., and Mawer, G. E. (1970). The digestion and absorption of protein in man. 1. The site of absorption. British Journal of Nutrition, 24, 227-240.

Peters, T. J. (1970). The subcellular localization of di- and tri-peptide hydrolase activity and guinea-pig small intestine. Biochemical Journal, 120, 195-203.

Peters, T. J., and MacMahon, M. T. (1970). The absorption of glycine and glycine oligopeptides by the rat. Clinical Science, 39, 811-821.

Rhodes, J. B., Eichholz, A., and Crane, R. K. (1967). Studies on the organisation of the brush border intestinal epithelial cells. 4. Aminopeptidase activity in microvillus membranes of hamster intestinal brush borders. Biochimica et Biophysica Acta, 135, 959-965.

Robinson, G. B. (1963). The distribution of peptidases in subcellular fractions from the mucosa of the small intestine of the rat. Biochemical Journal, 88, 162-168.

Sigrist-Nelson, K. (1975). Dipeptide transport in isolated intestinal brush border membrane. Biochimica et Biophysica Acta, 394, 220-226.

Silk, D. B. A. (1974). Peptide absorption in man. Gut, 15, 494-501.

Silk, D. B. A., and Kim, Y. S. (1975). A study of intraluminal peptide hydrolase activity in the rat. Clinical Science and Molecular Medicine, 49, 523-526.

Silk, D. B. A., and Kim, Y. S. (1976). Release of peptide hydrolases during incubation of intact intestinal segments in vitro. Journal of Physiology, 258, 489-497.

Silk, D. B. A., Perrett, D., and Clark, M. L. (1973). Intestinal transport of two dipeptides containing the same two neutral amino acids in man. Clinical Science and Molecular Medicine, 45, 291-299.

Silk, D. B. A., Perrett, D., Webb, J. P. W., and Clark, M. L. (1974a). Absorption of two tripeptides by the human smal intestine: a study using a perfusion technique. Clinical Science and Molecular Medicine, 46, 393-402.

Silk, D. B. A., Webb, J. P. W., Lane, A. E., Clark, M. L., and Dawson, A. M. (1974b). Functional differentiation of human jejunum and ileum: a comparison of the handling of glucose, peptides, and amino acids. Gut, 15, 444-449.

Wilson, F. A., and Dietschy, J. M. (1974). The intestinal unstirred layer: its surface area and effect on active transport kinetics. Biochimica et Biophysica Acta, 363, 112-126.

Wojnarowska, F., and Gray, G. M. (1975). Intestinal surface peptide hydrolases. Identification and characterization of three enzymes from rat brush border. Biochimica et Biophysica Acta, 403, 147-160. 